\title{
Resilience challenges for textile enterprises in a transitional economy and regional trade perspective - a study of Kyrgyz conditions
}

\author{
Mansur Abylaev* \\ The Swedish School of Textiles, \\ University of Borås, \\ Allégatan 1, 50190 Borås, Sweden \\ and \\ The Parliament of the Kyrgyz Republic, \\ Av. Chui, 205, 720000 Bishkek, Kyrgyzstan \\ Fax: +996312639204 \\ E-mail: abylaev@gmail.com \\ *Corresponding author
}

\section{Rudrajeet Pal and Håkan Torstensson}

The Swedish School of Textiles, University of Borås, Allégatan 1, 50190 Borås, Sweden

Fax: +46-33-435-40-09

E-mail: rudrajeet.pal@hb.se

E-mail: hakan.torstenssion@hb.se

\begin{abstract}
This paper aims to contribute to the resilience development of the textile sector in a transitional economy, based on a case study of the Kyrgyz Republic, where the transition to a free market system generated broken supply chains, low diversification, a high open economy level of the textile sector and dependence on international trade regulations. The approach used is based on theories of organisational resilience, literature studies and fieldwork. Scenarios are developed and analysed by event tree and SWOT analysis, to identify resilience properties of the textile sector. Findings focus on the implications of future membership or non-membership, respectively, in the Customs Union of Belarus, Kazakhstan and Russia, where both supportive and adverse effects have been identified. The results contribute to the knowledge of the transitional economy conditions and serve as a guideline for stakeholders about enhancing resilience, both at the industrial and organisational levels, of the Kyrgyz textile sector.
\end{abstract}

Keywords: organisational resilience; supply chain risk; regionalisation; Customs Union; transitional economy; Kyrgyzstan; textiles and apparel.

Reference to this paper should be made as follows: Abylaev, M., Pal, R. and Torstensson, H. (2014) 'Resilience challenges for textile enterprises in a transitional economy and regional trade perspective - a study of Kyrgyz conditions', Int. J. Supply Chain and Operations Resilience, Vol. 1, No. 1, pp.54-75. 
Biographical notes: Mansur Abylaev is a visiting doctoral candidate at the Swedish School of Textiles, University of Borås, and a $\mathrm{PhD}$ student in the Kyrgyz National University. His areas of research are organisational resilience, international trade integration and business continuity in transitional economy. $\mathrm{He}$ is a Senior Lecturer in international economic relationships and economic calculation in Kyrgyz National University. He also works as an expert in the Committee on Economic and Fiscal Policy of the Kyrgyz Parliament.

Rudrajeet Pal is a Post-Doctoral Research Fellow at the Swedish School of Textiles, University of Borås, Sweden in the field of Engineering Management. $\mathrm{He}$ holds a $\mathrm{PhD}$ in Engineering Science, with specialisation in operations and strategic resilience. His additional areas of research and interest relate to business model innovation and change, business engineering, supply chain management and fashion logistics. He is also a Lecturer in Supply and Demand Chain Management, Fashion Logistics and Supply Chain Risk and Resilience. He has 25 publications in conferences and journals in these fields.

Håkan Torstensson is a Professor in Transportation Safety and Logistics at the University of Borås since 2001. His areas of research expertise focus on risk and security in logistics systems, supply chain management, and textile management. His previous experience includes several years in different management positions at the Swedish Technical Research Institute, Project Leader in Transportation Safety and Risk Assessment and President of the European Environmental Engineering Societies. He has been teaching logistics, information technology, packaging technology, risk assessment, recovery engineering, supply and demand chain management and applied textile management over several years.

This paper is a revised and expanded version of a paper entitled 'Supply chain resilience of Kyrgyz textile companies in regional international trade integration' presented at the 18th International Symposium on Logistics, ISL 2013, Vienna, July 2013.

\section{Introduction}

The Kyrgyz textile industry had a stable development during the Soviet period, due to the favourable agricultural and structural predisposition of Central Asia. During the Soviet time, the textile sector was dominated to $80 \%$ by fabric and thread production (Birkman et al., 2012). The agricultural orientation of the regional economy was suitable for cotton, woollen and silk fabrics and thread production (ILO, 2012). Most companies had modernised their machinery in the 1980s and possessed modern production lines.

However the transition from planned economy to free market by 'shock therapy' caused severe disturbances and demonstrated a low level of resilience of the post-Soviet textile sector. The 'shock therapy' was aimed at fast economic reforms and recovery, inspired by the example of Poland's reforms (Sachs, 1994b). As a result the Kyrgyz Government began vast privatisation of the state-owned textile enterprises that subsequently modified the structure of the textile value chain. The liberalisation of economic activities, the market conjuncture and the Kyrgyz Government's policies for the textile sector contributed to the discrepancies of the textile value chain (Birkman et al., 2012). The once big production lines with several thousand employees were increasingly underused in their production capacity, as they did not permit economies of 
scale. International trade liberalisation saturated the domestic market with cheap, fashionable but low-quality textile production mainly from China and Turkey (ILO, 2012). The new owners of the huge textile enterprises, with obsolete production technology and without basic knowledge of management in a market economy, could not challenge to compete with imported goods in the domestic market (Birkman et al., 2012). Loss of outlets and costly production of natural and out-of-fashion fabrics contributed to the insufficient demand on the domestic market as well. Overall, low flexibility, low adaptation capacity and fast reform of the industry made most of the large textile producers bankrupt, as a result of abandoning the command system.

Economic cooperation with foreign entities, developed after the liberalisation of international trade, altered the supply chain structure and the organisational form of textile enterprises. Upstream production by large factories from the Soviet period was replaced by a large number of small and medium-sized enterprises (SMEs) with deep specialisation in downstream activities (USAID, 2011; ILO, 2012). That was also a result of governmental policy of SME stimulation and international trade policy.

The favourable international market conjuncture of sourcing and distribution of textile production provided an opportunity for the Kyrgyz textile enterprises to take part in global value chains. Comparative advantages of new sewing SMEs on the international market were accessibility to foreign markets, due to the free trade agreement of the Commonwealth of Independent States (CIS), abundance of raw materials, due to the weight-based system of customs duties for import, and low production input factors in the country (Birkman et al., 2012).

On one hand, the membership of the Russian Federation in the World Trade Organization (WTO) decreased competitiveness of Kyrgyz textile production after lowering protectionist measures of Russia toward South Asian garments. On the other hand, regionalisation processes of the Customs Union of Belarus, Kazakhstan and Russia (henceforth Customs Union), which are the primary countries for Kyrgyz textile export, imply $95 \%$ of the apparel produced is exported to Russia and Kazakhstan with insignificant internal market development (Birkman et al., 2012). In the difficult geopolitical situation in Central Asia, Kyrgyz authorities have demonstrated a political intent of integration to the Customs Union from 2015. A loss of Kyrgyz authorities' sovereignty in trade policy-making reveals itself in aligning international trade policy of Kyrgyzstan to the Customs Union and enlarging external borders outside of Kyrgyz territory. An extremely low diversification of raw material sourcing and export markets implies a high dependency of companies' economic performance on supply chain resilience. The evolution of international trade integration also risks to modify the existing supply chain and to challenge the resilience of the whole Kyrgyz textile industry.

In this context, previous investigations by the Kyrgyz National Institute of Strategic Studies have focused on making strength-weakness-opportunity-threat (SWOT) analyses of future adhesion to the Customs Union for Kyrgyz economy. ${ }^{1}$ The Institute of State Policy has made sector analyses of the Kyrgyz textile sector with recommendations for sustainable development to maintain comparative advantages of Kyrgyz enterprises. Periodically, the Ministry of Economy of the Kyrgyz Republic has taken initiatives to sectorial analyses to generate five-year prognoses of textile sector development. Also international organisations, like the German Society for International Cooperation, United Nations Development Programme (UNDP) and the US Agency for International Development (USAID) through local development programmes, have published analytical works on the textile sector development. 
However, there has been a lack of more scientific explanations to the effect of the abovementioned economic processes (viz., liberalisation, regionalisation, trade integration, etc.) in the context of the Kyrgyz textile sector, dominated by sewing SMEs, as well as analyses of the success factors and subsequent explanations of the profile of the 'state of resilience' of the sector over time. In this regard, the paper aims to contribute to the existing knowledge gap about the 'states of industrial resilience' of the Kyrgyz textile sector amidst various economic processes, viz. transitional period and trade liberalisation, regionalisation, and plausible accession to Customs Union. Many studies have analysed which factors and industry structures support the growth of an industry in a specific region (cf, Brenner, 2004; others), while the sources of regional resilience have only been analysed sparsely (Fingleton et al., 2012; Martin, 2012). Fingleton et al. (2012) hence academically industrial resilience in a transitional economy perspective adds novelty as well.

\subsection{Purpose of the paper}

The main purpose of the paper is to investigate the effects of the regionalisation processes on the 'state of resilience' of the Kyrgyz textile sector in order to provide a basis for adequate redesigning of its supply chain in the foreseeably changing international trade environment. The main research questions (RQs) are as follows:

1 What factors characterise the 'state of resilience' of the existing Kyrgyz textile sector?

2 Can the Kyrgyz textile sector retain its comparative advantage on export markets in the regionalisation process?

3 What are the antecedents for developing resilience of Kyrgyz textile sector in probable international trade scenarios in the future?

Through an analysis of the resilience of the Kyrgyz textile sector during the transitional period in the first part, authors will in the second part highlight plausible effects of future international trade integration scenarios.

\section{Literature review}

Arising from the RQs posed above the context of this research is a combination of the economic processes (along 'shock therapy', regionalisation and globalisation perspectives) and resilience (at the industrial and organisational levels over time), which provides our theoretical vantage point.

\subsection{Economic processes - 'shock therapy', regionalisation and globalisation}

The 'shock therapy' perspective (also called 'Big Bang' strategy), followed by the globalisation and regionalisation processes, explains the complex transitional phase of the Kyrgyz economy in the post-Soviet era since 1990.

Shocks in economics refer to unexpected or unpredictable events that affect an economy, either positively or negatively. The notion of 'Big Bang' or 'shock therapy' for economies is considered to transform the command economy to a free market economic 
system through rapid degrees of economic liberalisation, particularly through strong price and currency controls, withdrawal of state subsidies leading to privatisation of state-owned assets, and immediate trade liberalisation (Sachs, 1994b; Åslund et al., 1996). Such radical programmes under 'shock therapy', as advocated by Jeffrey Sachs, are expected to lead to quick, large-scale privatisation of previously public-owned assets (Lipton et al., 1990; Sachs, 1994a), while the issues of society and economics take a secondary role. The principal neo-liberal argument for this strategy is rapid liberalisation by limitation of government intervention on economy that causes economic and monetary disorder, however, 'gradualism' has been proposed to be more sustainable for leading long-term economic reforms (Czap and Nur-Tegin, 2011).

Another critical aspect related to liberalisation of economic processes, associated with 'shock therapy', is the ambiguous relationship with regionalisation. On one hand, it leads to regional decentralisation (promoting liberal economic policies and privatisation), while on the other hand it leads to regional aggregation (with more or less defined internal political structures) (Fernandez-Jilberto and Mommen, 1998).

Regionalisation is another key context for the present research in terms of Kyrgyz membership in the CIS free-trade agreement and possibilities of future accession to the CU. Regionalisation focuses on regional and interdependent dynamics (of a set of countries) along various aspects, such as geographical proximity, international interaction, sharing of collective goods, cohesiveness, and marginalised trade barriers. (Katzenstein, 2000; Freire and Cierco, 2007). Regional aggregation is considered as both a defensive mechanism to safeguard regional policies, economy and interests (e.g., by creating economic protection measures) that might pose a threat to global trade, and also a response to global challenges (like capital flows, global economic recession and trans-border ecological problems) (Scholte, 2000; Kuhnhardt, 2002; Hettne and Soderbaum, 2005). Thus, this creates a multi-level view of regions, linked to both the larger international system and different national systems, thus generating a growing tension (Katzenstein, 2000). For example, take the case of European regions such as the Scandinavian countries or the Balkan region as a fundamental expression of regionalisation with their positioning and integration into the European Union (Freire and Cierco, 2007).

Moreover, linking regionalisation and globalisation, by referring to the multiplicity of linkages and interconnections to address political, social, economic and security challenges of the international order, is critical in a post-communist change (Freire and Cierco, 2007). Globalisation between international actors is seen as a driving force in promoting new opportunities for economic growth and social development through market expansion, increases in global interdependence through science and technology, democratisation, and increased cooperation (Scholte, 2000, 2002; Kuhnhardt, 2002;). The Ricardian theory of international trade highlights the comparative advantage of nations participating in such globalised trade and forms a platform for the Heckscher-Ohlin international trade model. This model demonstrates that a nation produces goods that use factors of production that are relatively abundant locally. Aligning input factors of production in free movement of capital and labour, described in classical theory, generates risk of increased wages and cancels existing comparative advantages in international free trade.

For labour-driven industries, like textile and apparel, the challenges of globalisation and international free trade have resulted in delocalisation of Western production to low-wage, low-cost nations. The movement of production due to cost-efficient input 
factors of production is shown in a World Bank Report of Frederick and Gereffi (2009). As the cost of production has increased in the Pacific Asian countries, new producers like China have emerged in the 1980s, while the former apparel producers have delocalised low value-added assembly stages of production and specialised in higher capital-intensive processes at upstream level (Gereffi and Memedovic, 2003; Gereffi and Frederick, 2010). The recent shifting describes the specialisation of China in production of fabrics, and new actors like Bangladesh (having higher labour density) offering even lower wage costs for the assembly stages. These new actors are forced to work in a triangle manufacturing scheme (Gereffi and Fernandez-Stark, 2011) that presumes delegation to existing Chinese partners to find low wage cost country producers, without contracting directly from the Western countries.

\subsection{Industry and organisational resilience}

In the context of trade liberalisation and regionalisation, the notion of industrial resilience for regional economic evolution is critical (Simmie and Martin, 2009). Such regional industrial resilience is essential for developing adaptive capability to adjust and overcome various internal and external shocks (McGlade et al., 2006; Holm and Østergaard, 2013). Only a few researchers have analysed aspects of regional industrial resilience (cf, Martin, 2012; Fingleton et al., 2012); while Fingleton et al. (2012) analysed the impact of economic recessions on future employment growth in UK regions, Martin (2012) has provided the theoretical argumentation for how adaptive resilience and its antecedents depend upon the level of new firm formation, firm innovativeness, firms' willingness to change, diversity of the regional economic structure, and availability of skilled labour. Holm and Østergaard (2013) have recently provided an account of regional industrial resilience of the Danish ICT sector that had experienced the shocks of the dot-com bubble and economic recession of 2000-2001. Moreover, regional resilience might also be higher in regions with large firms, as they are more resistant to shocks, as compared to regions with mostly start-ups and SMEs (Holm and Østergaard, 2013). At the industry level, resilience is presumably characterised by how the region's industrial, technological, labour force and institutional structures adapt to the changing competitive technological and market pressure and shocks (Simmie and Martin, 2009). Location-specific externalities also have a significant effect on the industrial resilience across regions influenced by the size, age and human capital of the firms (Holm and Østergaard, 2013). Other factors influencing significantly the level of industrial resilience in a region are related to differences in the regional stock of inputs, such as knowledge, skills, and natural resources, or the initial structure of the industry (Beardsell and Henderson, 1999). It is also quite logical to claim that the industrial resilience is highly influenced by individual resilience of the firms embedded in it, if the firms are highly similar in their size, content, structure, capabilities and governance.

At the firm level, resilience is defined as the ability to bounce back from a disturbance before the crisis level is reached (Sheffi, 2007). Sheffi and Rice (2005) provide an account of various stages of firm resilience in the form of a disruption profile; such a disruption profile of an organisation can be depicted by its performance (can be in terms of sales, production level, customer service, or other relevant metric) vs. time and characterised by eight phases, viz. 
1 preparation - when a company foresees and prepares for the disruption

2 the disruptive event - when the high-impact/low-probability disruption takes place in real

3 first response - when the first response is generated to attend to the initial damage

4 delayed impact - when the full impact of the disruption is not felt immediately due to several reasons

5 full impact - when performance drops precipitously

6 recovery preparation - when the company starts preparing for recovery, almost in parallel to the first response

7 recovery - when the performance is restored, and finally

8 long-term impact - the long-lasting impact of the disruption (Sheffi, 2007).

Development of a firm's resilience over a period of time is influenced by a number of factors; from a resource-based view (RBV) perspective this is justified by the presence and development of various assets and resources (financial, physical, human, technological, organisational and reputational) (Freeman, 2004; Gittell et al., 2006; Pal et al., 2014). Existing studies (cf, Ghobadian and Gallear, 1997; Vossen, 199; Van Gils, 2005; Herbane, 2010) have highlighted how the lack of crucial resources, predominantly material, financial and technological, have led to the failure of firms. In designing resilient supply chains, Christopher and Peck (2004) recommend to keep several options of sourcing, despite the higher price of alternative sourcing, as it may provide an opportunity to reduce the impact of disruption. Risk management practices also encourage reducing geographical density of the sourcing map by regions to avoid shortage, if natural, political, social or economic disruptions touch a certain sourcing region. Another key essential for SME resilience is relational networks and strategic alliances; close relationships with upstream and downstream partners and external support are key factors of supply chain reinforcement (Gunasekaran et al., 2011; Pal et al., 2014).

Apart from assets and resourcefulness organisational core capabilities are effective in developing resilience (e.g., long-term flexibility, redundancy and robust responses) (Sheffi, 2007). Such dynamic capabilities form a key determinant of organisational flexibility or 'adaptive capacity', crucial for developing resilient response (Burnard and Bhamra, 2011; Holm and Østergaard, 2013).

Thus, the resilience of the sector is investigated from both industry and firm levels.

\section{Methods}

The paper is partly explorative and partly descriptive in nature. First, it investigates the existing situation of the Kyrgyz textile industry and attempts to evaluate its 'state of resilience'. This is followed by identifying and developing the plausible scenarios in a Kyrgyz international trade context, to investigate the plausible future 'states of resilience'. Finally certain preliminary guidelines are prescribed for the present industry stakeholders, in particular the large number of sewing SMEs, to survive in this changing context. 
Official data related to industry statistics (tariff rates, balance of trade, export-import volumes, etc.) was collected from the National Statistics Committee of the Kyrgyz Republic and reports published by the WTO to comprehend the actual situation of the international value chain of Kyrgyz textile industry. This secondary official data was complemented by information obtained from a series of interviews conducted by the authors.

The purpose of the interviews was to get a better estimation on the shadow economy for corrections of the official data describing the developmental profile of the Kyrgyz textile industry. One of the authors was also engaged in a position as an expert for the Kyrgyz Parliament for over three years, which provided primary insight on the topic. This was cultivated to organise interviews with local and international experts on the Kyrgyz textile industry, officials of governmental bodies and representatives of the industry, owners and managers of textile SMEs, and head of the LegProm (Association of Light Industry of the Kyrgyz Republic). The main objective of the interviews was to draw the actual international trade map and value chain of Kyrgyz textiles and identify the existing 'state of resilience' and risks for the industry in a changing international trade regulation context. The interview questions aimed at identifying difficulties of development and vulnerable points of production, value chain and international trade of textile enterprises, organisation support for Kyrgyz textile entrepreneurs, and a discussion of research and results of international organisations in the field.

All the interviews were conducted face to face by the main author, divided in two rounds. In the first round (aimed at investigating along RQs 1 and 2), interviews were carried out with the local and international experts from the Kyrgyz textile industry. The local experts for interviewing were selected on the basis of their previous association with the Kyrgyz National Institute of Strategic Studies in conducting investigations of the country's textile industry in different perspectives. Along with that, an international expert on textiles was selected from the Sustainable Economic Development Programme of the German Society for International Cooperation in Kyrgyzstan. Insight in the current state of the Kyrgyz textile industry was also collected through interviews with owners of Kyrgyz textile SMEs, producing socks, garments and home textiles, and also with the head of LegProm.

The second round of interviews was carried out with officials from the ministry to gain insight into the official discussion on processes of adhesion of Kyrgyzstan to the Customs Union (following RQ 3). The selected interviewees were the Deputy Minister of energy and industries of the Kyrgyz Republic, the Head and Deputy Head of the Committee on economic and fiscal policy of the Kyrgyz Parliament, the Director and Deputy Director of the Kyrgyz National Institute of Strategic Studies and the Head of LegProm.

The main purpose of these later interviews was to clarify issues related to difficulties of integration in the CU, tax and tariff modification points, main clauses of the adhesion, and possible facilities for Kyrgyz post-membership.

The compilation of these subjective visions of all interviewees on organisational development of Kyrgyz textile industry, international trade orientation, value chain mutation and textile enterprises' resilience, conducted in two rounds, was considered essential in improving the construct validity of the interviewing technique (Yin, 2009). The nature of open-ended interviews conducted was also essential - in developing the event tree and SWOT analyses - to address any rival explanation, 
related to the transitional profile of the 'state of resilience' of the Kyrgyz textile industry, thus strengthening the internal validity of the research (Guba and Lincoln, 1989; Yin, 2009).

Collected data was analysed through interpretive content analysis of the secondary sources. The unit of analysis has been 'state of resilience' from both industrial and firm levels. The analysis was carried out by the main author, at first, supported by his understanding of the plausible situations and 'states of resilience' of the Kyrgyz industry from his long association with the Parliament. To increase the reliability of the analysis, the co-authors verified the analysis individually (Guba and Lincoln, 1989; Yin, 2009). For answering the RQ 3 an event tree analysis was performed to logically evaluate the series of subsequent events and their consequences, following the various plausible trade integration scenarios for Kyrgyzstan. Subsequently, SWOT analyses were also made for each identified scenario. This qualifies the research process as action research (McNiff and Whitehead, 2002) as the main author's active part in the research (to identify the future 'state of resilience') is instrumental in developing normative guidelines that can sufficiently influence policy making, because of his long association with the Parliament.

\section{Findings}

The findings address three critical economic aspects related to the Kyrgyz textile sector to determine the present and future 'states of resilience'. First, the influence of the international integration on the non-Kyrgyz textile sector in a transitional period is evaluated. This is done by investigating the effects of international trade liberalisation and subsequent accession to WTO. Next, the effects of the trade regionalisation (the formation of the Customs Union) and the globalisation of the major trade partners (namely Russia) in relation to the Kyrgyz textile sector have been studied. Finally, scenario planning is conducted by looking into the effects of two main plausible scenarios, viz.

1 integration within the Customs Union

2 non-integration with the Customs Union, respectively.

\subsection{International integration influence}

The dilemma of international trade liberalisation in the medium term is the import trade facilitation that developed the Kyrgyz textile sector. As the first former Soviet country Kyrgyzstan joined the WTO in 1998. By the obligations taken during accession to the WTO Kyrgyzstan should have customs duties at a level below 10\%. Previously, the Kyrgyz customs duties for import of textile productions were established at $10 \%$ in 1996 , so integration into the WTO had no great influence on international trade of the Kyrgyz textile production. But in 2003 the $10 \%$ import customs duty was changed to a weight-based system of taxes on import by a decree of the Kyrgyz Government to boost production of textile sewing enterprises by providing cheap raw materials. The flip 
side was the inability of upstream level producers to compete with cheap and fashionable imported fabrics on the internal market, hence leading to bankruptcy of most of them.

On the other hand, international trade regulation facilities generated several open air markets next to Bishkek that later became a cluster concentration with $98 \%$ of the apparel production. Garment manufacturers could find Chinese and Turkish cheap fabrics and accessories through nearby sourcing that decreased the lead time for Russian and Kazakh private agents' orders. Preferences for production of countries in the CIS on Russian and Kazakh markets by the CIS free trade agreement allowed Kyrgyz garments to be competitive. On one hand the CIS free trade agreement implies removal of any duty except the VAT from other CIS countries, while on the other hand the Russian and Kazakh markets were protecting their internal textile industries by high import taxes against third countries, including China. According to SIAR research and consulting the result was a raise in apparel production volume by 35 times between 1994-2008, where $90 \%$ of the production went for export, mainly to Russia and Kazakhstan. Thus after fast international trade integration Kyrgyzstan's customs policies facilitated cheap import of textile fabrics and cost efficient export of garments.

\subsection{Changing environment of international trade regulation}

\subsubsection{Integration to regional trade organisation}

The new format of regionalisation through the creation of the Customs Union between Russia, Kazakhstan and Belarus in 2010 has resulted in liberalisation of financial and commercial movements between the member countries. The main purpose of the Customs Union is the development of economies by a reduction of lead time by a factor of four, motivated by absence of physical customs borders, and the development of intra-regional trade for stimulation of economic growth in a long-term perspective. This favourable international trade conjuncture besides the development of the sewing sector also generated re-export of Chinese apparel with the label 'made in Kyrgyzstan'. Kyrgyzstan, in the form of an immense open air market-place, became an international trade hub for neighbouring countries, where foreign private retailers could make wholesale purchases. According to the National Statistics Committee the share of international trade with the Customs Union countries are $42.7 \%$ (Russia $27.6 \%$; Kazakhstan 12.7\%; Belarus 2.4\%) (National Statistics Committee, 2013). The share of export to Russia out of export to all CIS countries was at $27.9 \%$ (USD 284.4 million), of which $47.7 \%$ textile sector export (National Statistics Committee, 2013).

After the creation of the Customs Union Kyrgyzstan still benefits from the CIS countries' free trade agreement, but the barriers are getting a non-tariff form as import procedural hurdles. The CIS free trade agreement is a basic level of regional integration, which does not mean aligning trade policy of countries and does not exclude bilateral tariff modification of trading partners on different goods. This agreement can be applied only for goods that have more than $30 \%$ value added in the exporting country to exclude re-export of goods. 


\subsubsection{Globalisation of regional trading partners}

Liabilities of Kyrgyzstan, assumed during the membership in WTO in 1998, were to maintain the average of import tariffs at a level of 5.6\%. After entering the Customs Union, Kyrgyzstan would have assumed the average level of import rate of the Customs Union at $10.1 \%$. Since membership of the Russian Federation in the WTO in August 2012 the context of the Kyrgyz membership in the Customs Union has been modified. Russian authorities took liabilities in the WTO membership negotiations to reduce the weighted average of its import taxes from $9.6 \%$ to $7.8 \%$. The transitional period of membership to the WTO is in progress till 2015, when Russian import policy must align all temporary rates to its liabilities under the WTO. As Russia has core importance in the Customs Union with over $90 \%$ of the GDP (of the whole CU) and $57 \%$ rights in decision-making (Vilpišauskas et al., 2012), the unique import policy of the Customs Union has to be aligned to tariffs of Russian obligations in the WTO, regardless of that Belarus and Kazakhstan are still in the process of negotiations to become members of the WTO.

For the textile sector, Russian customs duties were in the first steps of reduction of import taxes. According to the Chamber of Commerce of the Russian Federation the average of import tariffs were decreased from 15.07 to $9.9 \%$. Since the fall 2012 real customs duties of the Customs Union reduced on average by one third for all apparel sectors: from $10 \%$ but minimum 5 euro per $\mathrm{kg}$ to $10 \%$ but minimum 3 euro per $\mathrm{kg}$ for male outer garments, and from $10 \%$ but minimum 3 euro $/ \mathrm{kg}$ to 2 euro $/ \mathrm{kg}$ for female shirts, etc. On one hand, a decrease in tariff barriers for textile import of Russia and the Customs Union makes it easier to find compromising liabilities for Kyrgyzstan between obligations under the WTO and the Customs Union, respectively. On the other hand, Kyrgyz textile export to the territory of the Russian Federation is threatened by increased competition, since the customs barriers for garments from Southeast Asian producers are reduced after Russian membership in the WTO.

A comparison of liabilities of Kyrgyzstan in the WTO and the Customs Union memberships (cf, Table 1) demonstrates the raise of tariff barriers for import of fabrics, thread and apparel accessories after membership in the Customs Union.

Table 1 Tariff rates of Kyrgyzstan

\begin{tabular}{lccc}
\hline Commodity & $\begin{array}{c}\text { Current rate } \\
(\%)\end{array}$ & $\begin{array}{c}\text { Liabilities of KR } \\
\text { under WTO }(\%)\end{array}$ & Rates of Customs Union (\%) \\
\hline Cotton fabrics & $0-10$ & $5-10$ & $5-15$ \\
Cotton threads & 10 & 10 & 15 \\
Synthetic fabrics & $0-10$ & $5-10$ & $5-10$ \\
Synthetic threads & 0 & 5 & $5-10$ \\
Apparel accessories & 10 & 10 & 15 \\
Apparel & $10-12$ & $10-12$ & 10, not less than 1.5-3 EUR per kg \\
Sewing machines & $0-10$ & 10 & 0 \\
\hline
\end{tabular}

Source: Sectoral analysis of textile and apparel production of the Kyrgyz Republic, Kyrgyz National Institute of Strategic Studies, 2012 


\subsection{Scenario planning of the Kyrgyz membership in the Customs Union}

Lately the international textile market observes a rise of post-Soviet countries as new actors of the global value chain. South-south trade trends, described by Milberg and Winkler (2010), can be noticed by the development of consumer purchasing capacity of emerging countries like Russia and Kazakhstan. CIS countries tend to deal with each other, due to established logistical connections, historical background and language facility. Moreover, recent Russian recuperation of geopolitical influence on the Central Asian region by a regionalisation process boosts development of the textile sector. The membership in the Customs Union is a demonstration of Kyrgyz authorities' vector of integration in the intensified geopolitical stake of influence in the Central Asian region.

Figure 1 shows an event tree with qualitative probabilities of development of Kyrgyz trade integration in a geopolitical context and the possible economic effects on the textile sector. Two main scenarios highlighted are Kyrgyz accession and non-accession to Customs Union. The bolder lines suggest the more probable scenario in the future, as considered by the authors (i.e., the probability of Kyrgyz membership in the Customs Union is the highest, probability of Kyrgyz membership in the Customs Union with two to three years transitional period is medium, while probability of non-membership in the Customs Union is lower).

Figure 1 Scenario planning of international trade integration of Kyrgyzstan (see online version for colours)

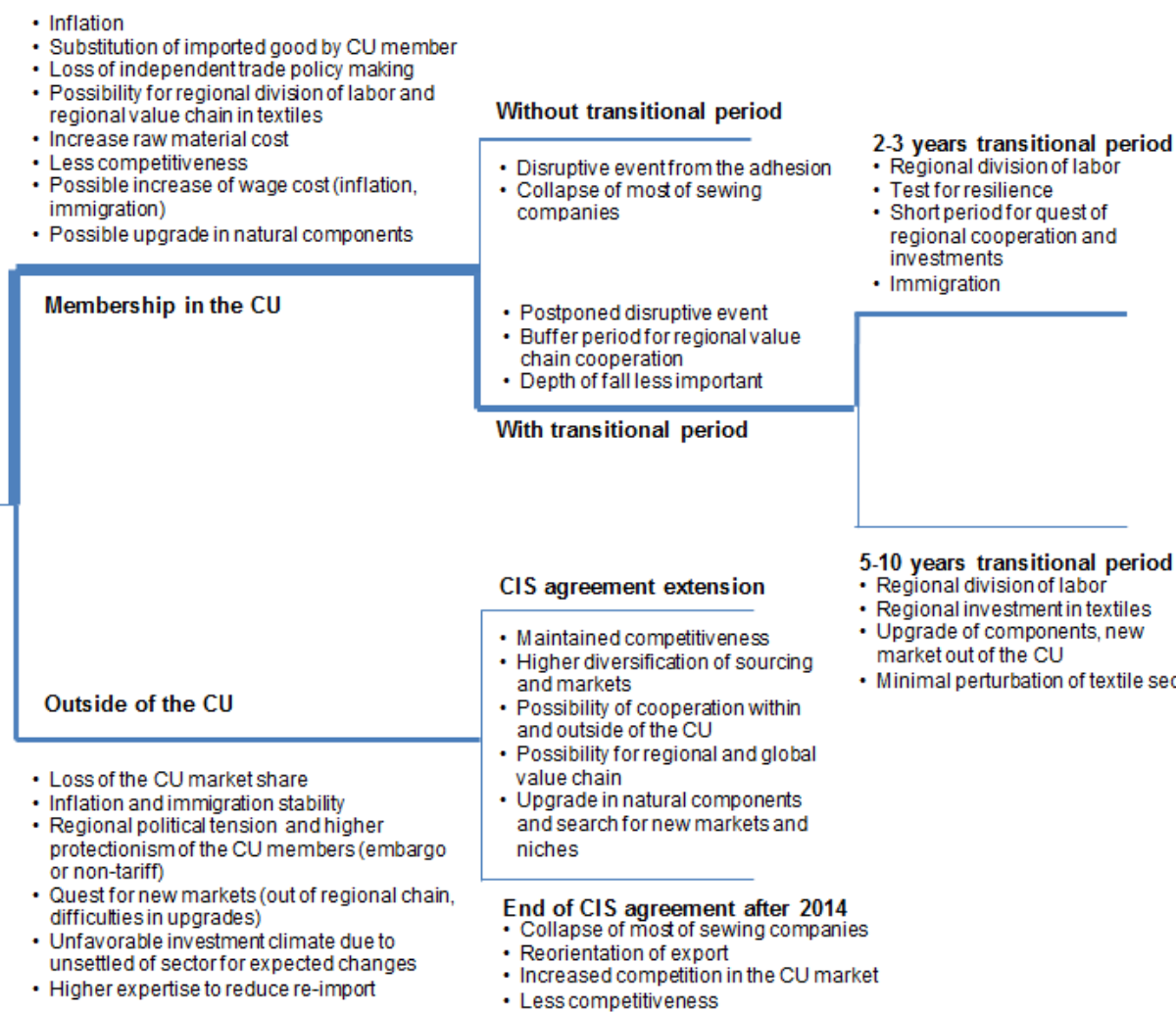

End of CIS agreement after 2014

- Collapse of most of sewing companies

- Reorientation of export

- Increased competition in the CU market

- Less competitiveness 
The political decision of integration in the Customs Union, as a probable scenario from 2015, would result in the Kyrgyz textile SMEs having access to the Customs Union market without any tariff barriers. On the Russian market the import tax-free regime will be continued after the end of the CIS free trade agreement, while the Kazakh market, which is bilaterally closed now for legal export of Kyrgyz apparel, will be approachable and current illegal export will take legal shape. As Kazakhstan and Belarus, non-members of WTO, still protect their textile markets, the market share of the Kyrgyz textile sector will increase in the short-term. Established cooperation with agents, growing popularity of the 'made in Kyrgyzstan' brand on these markets and Soviet heritage logistics facilities will support an export rise to the Customs Union members.

On the other hand, the lowest input factors (wage cost, local rent and electricity) of Kyrgyz economy will be attractive for investment in textile for the Customs Union members, and possible cooperation with fabric producers can develop into a regional division of labour to create a regional value chain. Such vertical international production integration has a better chance to take place, if the transitional period to the Customs Union is longer, for better marketing of Kyrgyz textile sector on these markets. In a longer perspective the whole Customs Union market will be less protected and exposed to import from external countries after the WTO membership of Kazakhstan and Belarus. That can limit increase of Kyrgyz textile export, due to aggravated competition with South Asian garment producers on the Customs Union market.

Customs Union membership opens up two more plausible scenarios, one with a transitional period as a time buffer for the alignment of all Kyrgyz policies with the CU, while the other one without a transitional or grace period. Depending upon the possible duration of transitional period, there could be a medium-term scenario (two to three years of transitional period) or long-term scenario (five to ten years of transitional period). On the condition that the transitional period allows garment manufacturers to pass from the existing international value chain to regional networking within the Customs Union, negative impact for the textile sector can be minimal or even avoided. A less optimistic scenario would be a transition period for a middle term of two to three years. Table 2 highlights the strengths, weaknesses, opportunities and threats for the Kyrgyz textile sector in case of membership in the $\mathrm{CU}$, with and without a transitional period.

Table 2 SWOT analysis of membership of Kyrgyzstan in the Customs Union

\begin{tabular}{ll}
\hline Strengths & Weaknesses \\
\hline - Access to the Customs Union market & - Lack of raw materials and price inflation \\
- Standardisation reduces non-tariff & - Substitution of cheap Chinese raw \\
barriers & $\begin{array}{l}\text { materials by the Customs Union member } \\
\text { analogues }\end{array}$ \\
- Low input factors of all the Customs & - Lower competiveness against South Asian \\
Union members & garments due to increased price \\
- Use of brand 'Made in Kyrgyzstan' & - Soss of market share in the Customs Union \\
- Logistics communication & \\
- Experience in work and established & \\
networking & \\
\hline
\end{tabular}

Note: In italic for without a transitional period. 
Table 2 SWOT analysis of membership of Kyrgyzstan in the Customs Union (continued)

\begin{tabular}{|c|c|}
\hline Opportunities & Threats \\
\hline $\begin{array}{l}\text { - Investment (manufacture centre of the } \\
\text { Customs Union) } \\
\text { - New cooperation with new partners within } \\
\text { the Customs Union } \\
\text { - Regional value chain with regional } \\
\text { division of labour } \\
\text { - Use of economy of scale after cooperation } \\
\text { with partners } \\
\text { - Work out of shadow for most exporters to } \\
\text { Kazakhstan } \\
\text { - Possible upgrade in value chain and } \\
\text { natural components } \\
\text { - Relocation of textile sector production } \\
\text { from Customs Union members }\end{array}$ & $\begin{array}{l}\text { - Increase of wage cost, due to inflation and } \\
\text { free movement of labour within the } \\
\text { Customs Union } \\
\text { - Social discontent and strike of workers } \\
\text { - Maintaining non-tariff barriers } \\
\text { - Flexibility adaptation insufficiency for } \\
\text { resilience, and bankruptcy of the sector }\end{array}$ \\
\hline
\end{tabular}

Note: In italic for without a transitional period.

Table 3 SWOT analysis of Kyrgyzstan being outside of the Customs Union

\begin{tabular}{|c|c|}
\hline Strengths & Weaknesses \\
\hline $\begin{array}{l}\text { - Avoid price raise for raw material sourcing } \\
\text { due to modification of trade regulation }\end{array}$ & $\begin{array}{l}\text { - Temporary effect } \\
\text { - High dependency of political changes of } \\
\text { the Customs Union members } \\
\text { - Unsettled sector limits the increase of } \\
\text { investment in the sector } \\
\text { - Market share lost in the Customs Union } \\
\text { - Cost rise due to increased import rates of } \\
\text { - } \quad \text { the Customs Union }\end{array}$ \\
\hline $\begin{array}{l}\text { Opportunities } \\
\text { - } \quad \begin{array}{l}\text { Leeway for cooperation, regional and } \\
\text { global value chain participation and } \\
\text { division of labour }\end{array} \\
\text { - } \quad \text { Triangle manufacturing for the Customs } \\
\text { Union market } \\
\text { - } \quad \text { Upgrade in value chain in longer period } \\
\text { - Increased market share and economy of } \\
\text { - } \quad \text { Reale } \\
\text { Union to third countries }\end{array}$ & $\begin{array}{l}\text { Threats } \\
\text { - Increased political tension } \\
\text { - Higher protectionist measures in form of } \\
\text { non-tariff measures from the Customs } \\
\text { Union members } \\
\text { - Selective embargo for the textile sector } \\
\text { from the Customs Union } \\
\text { - Failure of Kyrgyz textile sector, due to } \\
\text { loss of competitiveness caused by tariff } \\
\text { barriers of the Customs Union }\end{array}$ \\
\hline
\end{tabular}

Note: Including end of the CIS agreement, in italic.

A pessimistic scenario is an eventual failure of negotiations with Customs Union members on terms of membership, as currently the relationship with Belarus is tense. Table 3 highlights the strengths, weaknesses, opportunities and threats of the Kyrgyz 
textile sector in case of its non-membership in the CU, with an added scenario of possible termination of CIS agreement after 2014.

Joining the Customs Union without any transitional period is less probable but still in consideration, which would have a critical immediate inflationary impact on economy. Imported raw materials for the textile sector would increase from USD 0.28 per $\mathrm{kg}$ to EUR 2 to 3 per $\mathrm{kg}$. This shock will increase the price of garments on the Russian markets. Due to increased price competition, consequences for the textile sector can be severe, as also the organisational resilience of Kyrgyz textile companies would be under question.

In case of membership both with and without transition period those textile enterprises diversifying their sourcing network within the Customs Union territory would have more comparative advantages than the ones undertaking preventive action in the preparation period of Kyrgyz entering the Customs Union.

The next section analyses the Kyrgyz textile sector's resilience as a function of time.

\section{$5 \quad$ Analysis and discussion}

In this section, we aim at making inferences on the 'states of resilience' of the Kyrgyz textile sector as a function of time, since its economic liberalisation in the post-Soviet period.

Fast economic reform led by 'shock therapy' and subsequent privatisation and trade liberalisation resulted in changing the industry and value chain structure. While the huge textile producers, now with obsolete technology and without basic knowledge of management in the free-market economy, could not compete with the import of cheap fabrics from adjacent markets, the small apparel sewing SMEs with low value addition developed in due time. A favourable market conjuncture, specific to the transitional period, such as low input production cost, informal business opportunities and other high investment requests, supported the fast development of the sewing sector. But the main influence on the Kyrgyz textile sector during the economic transformation period was due to the fast liberalisation of international trade and the geographical proximity to China. Business continuity of the whole sector as the economy forming branch is so far the main indicator of the Kyrgyz sewing sector's resilience.

Investigation of the value chain structure of most of these sewing SMEs suggests that their relatively small-scale purchasing capacity makes direct cooperation with Chinese and Turkish fabric and thread producers difficult. The SMEs with limited production capacity will have challenges in increasing their orders to be able to work directly with adequate raw material producers. This will raise the cost for stock keeping of raw materials and decrease their flexibility and operational resilience. This finding is in line with prior research by Pal et al. (2014) showing that excessive stock potentially inhibits economic resilience by affecting profitability, sales turnover and leverage ratios, thus compelling firms many times to depreciate their stock values and consolidate internal restructuring for higher efficiency planning. Inability to control rising fixed costs through stock management or to maintain production efficiency may lead to lack of long-term business continuity strategy as well (Pal et al., 2012).

Regional integration of Kyrgyzstan and globalisation of the Russian market after joining the WTO have also re-estimated the comparative advantages of the Kyrgyz textile sector on Customs Union markets. The resilience of the Kyrgyz SMEs to the changing 
environment depends on fluctuations of international trade regulations, as the share of Kyrgyz textile export to the Customs Union members is about $95 \%$. Mainly the future 'state of resilience' of Kyrgyz textile SMEs depends on two main changes in international trade regulations. On one hand, it is the decision for Kyrgyz membership in the Customs Union and its accorded transitional period, and on the other hand the possibility of prolongation of the agreement of free trade of CIS countries after 2014 is critical. These are discussed in the following sub-sections.

\subsection{Resilience as a function of time to convert global to regional value chain}

Accession to the Customs Union presumes end of import facilities for raw materials from countries outside the Customs Union. Loss of cheap raw material sourcing makes it necessary to redesign the supply chain to keep the Kyrgyz textile industry resilient. The main issue of the Kyrgyz textile sector on multilateral negotiations about integration in the Customs Union would be the terms of temporary import facilities accorded for textile raw materials trade. The transitional period of integration in the Customs Union would be assessed as a determinant of Kyrgyz enterprises' resilience. The main stake for the Kyrgyz side is to protect vulnerable production by negotiating a transitional period of the Customs Union membership, during which low tariffs would be applied for consumer goods import to limit inflation in the short-term and to ensure business continuity of production. The main issue is the protection of the textile industry, where it is specialised in low value-added assembling with low sourcing diversification, mostly outside the Customs Union territory.

After integration in the Customs Union, the external borders of the Customs Union will be extended to the Kyrgyz border to third countries by aligning international trade policy and establishing common import tariffs for all countries. Hence the comparative advantage of Kyrgyz apparel, mostly gained by abundance of imported raw material on the local market due to Kyrgyz international trade policy, will be under question. The disturbance of the supply chain caused by regionalisation processes will modify the sourcing matrix of Kyrgyz apparel producers. The bargaining results of the Kyrgyz authorities on transition period and terms of membership and preventive action of apparel SMEs to diversify sourcing and outlets would determine the depth and duration of the expected initial integration shock. Success in negotiations can even postpone the disruptive event by delaying the rise of customs duties for imported textile raw materials.

One of the main risks of membership would be raised wage costs as a response to inflation in a short time, which is fraught with increased social discontent and strikes of textile sector workers. Also in the long-term perspective, Kyrgyz business input factors will be aligned to the Customs Union members, due to free movement of capital and labour within the Customs Union. The Common Economic Space (CES), which is the next step of integration of the Customs Union members including free movement of goods, service, capital and labour, will be required for acceptance by Kyrgyz authorities after membership in the Customs Union (Birkman et al., 2012). These changes would imply a higher cost structure and hence product price, thus cancelling the existing comparative advantages of the Kyrgyz textile sector after entering the Customs Union. Free movement of labour and alignment of input factors within the Customs Union will raise the wage cost on the Kyrgyz labour market. Similar findings in Pal et al. (2014) suggest the implications of a hike in wages and production cost on low economic resilience. Moreover, a large negative trade balance and high dependency on imported 
goods will drive inflation and high substitution of raw materials by production by Customs Union members. Invariably such regulatory changes will significantly impact the fragile and vulnerable textile industry, which is very dependent on export.

\subsection{Risks and resilience of Kyrgyz textile development outside of the Customs Union}

Regardless whether the membership to the Customs Union is politically motivated, Kyrgyz economic dependence of trade with Customs Union members is apparent by the share of international trade of $42.7 \%$. Staying out of the Customs Union implies that the Kyrgyz textile sector is under the threat of higher export taxes and more frequent use of non-tariff barriers by Customs Union members for Kyrgyz apparel.

The option of Kyrgyz authorities to stay out of the Customs Union could be possible if Customs Union members insist on refusing membership of Kyrgyzstan or are not being supportive to the proposed transition period. It would raise international tension between the Customs Union countries and Kyrgyzstan and have an adverse influence on the economic relationships in terms of the Customs Union market being declared closed by embargo for Kyrgyz textile garments. Even non-extension of the free trade agreement of CIS countries is catastrophic for the resilience of the sector, as the market price would rise to the Customs Union import rate. Kyrgyz garments can lose its market share in the competition with Chinese garments, which have improved their competitiveness since Russia reified its import tariff obligations upon its membership in the WTO. An extreme dependency of the Kyrgyz textile sector on export to the Customs Union members can bankrupt the textile sector as well, as the time for recovery is longer than for adaptation to a changed environment by export diversification. This is in accordance with Pal et al. (2012) stating the role of market diversification (as growth plans) in favouring economic resilience. Clearly, non-association of Kyrgyzstan with the Customs Union along with end of CIS agreement after 2014 would lead the textile sector into a state of nonresilience.

A better but less probable development of the international trade integration process would be to stay outside of the Customs Union, but with a prolongation of the agreement of free trade with CIS countries. In this scenario both global and regional value chains can be affordable. This case would have the best impact in the short-term, as low import rates for raw material sourcing maintain the cost of garments manufactured in Kyrgyzstan and the competitiveness on the Customs Union market. Kyrgyz economy would be the best destination for investment of triangle manufacturing for Western countries in order to use low import rates for raw material sourcing and get access to the Customs Union markets, as was the case of Asian newly industrialised countries (NIC) in the 1970-1980s (Gereffi, 1999; Jin, 2004).

Again, higher diversification of outlet markets remains an option to absorb probable demand fluctuation of the Customs Union by searching export markets, in accordance with studies by Holm and Østergaard (2013) suggesting the important role of adaptability in developing industrial resilience. Further, maintaining internal inflation and substitution of goods by Customs Union import will keep business input factors low and avoid social strikes and immigration of workers in the textile sector. International trade policy independency would provide leeway for cooperation and networking with globally integrated textile partners, fully benefitting the market access facilitated by the Customs 
Union. This is supposed to improve the industrial resilience of the Kyrgyz textile sector, as was also evident in the studies of Pal et al. (2014) and Canello (2012).

In the longer perspective, value chain upgradation as well as searching for niches in natural component export to Western countries would be possible in the context of diversification of sourcing of raw materials from just Customs Union fabric producers. Such insertion of global value chains creates upgrading opportunities in industrial clusters, enabling higher competitiveness (Humphrey and Schmitz, 2002) and hence resilience. But the main advantages of such a scenario would be temporary, in effect limited by the extension period of the agreement.

\section{Conclusions}

This section of the paper is sub-divided into three parts, viz.

1 research implications

2 managerial implications

3 limitations and future research directions.

\subsection{Research implications}

The theoretical or conceptual contributions of this research relate to the two frames of reference addressed before, viz.,

1 economic processes of 'shock therapy', regionalisation and globalisation

2 industrial and organisational resilience.

In terms of the first construct, we gain insight of how a rapid liberalisation process can affect the content, structure and governance of a labour-driven manufacturing industry in a transitional economy. The research also provides a more specific understanding of the key structural characteristics of the Kyrgyz textile sector in terms of the shift in supply chain business model from large fabric producers (in the Soviet period) to a mix of assembly and full package SMEs. We also gain insight about the role of relational networking in a regional trade arrangement, with impacts of regional economic processes, tariffs and policies (formation of Customs Union and governmental intervention) to facilitate such cooperation.

Secondly, the knowledge of the 'states of resilience' and their antecedents provide a clear understanding of how resilience varies at the industrial level, due to various economic scenarios and policies and regulations embedded in it. This contributes to the knowledge of sources or antecedents of industrial resilience in regions, which have only been analysed sparsely so far.

\subsection{Managerial implications}

The research provides practical knowledge of the antecedents of 'states of resilience' for the Kyrgyz textile sector. Due to international market conjuncture the structure of the whole Kyrgyz textile industry was modified after having developed substantially during Soviet governance. Most of the fabric producers went bankrupt and large state-owned 
apparel companies fragmented into private textile SMEs. One of the success factors of the Kyrgyz textile SME development was the favourable international trade regulations and the geographical location, making Kyrgyzstan an international trade hub for neighbouring countries. The supply chain of the Kyrgyz textile SMEs relies on binding globally integrated producer countries of fabric and textile accessories, like China and Turkey, with regionally protectionist CIS countries by specialisation in apparel manufacturing. Kyrgyz apparel production, with low wage cost and cheap energy input, uses factors of production that enable specialisation in cut, make and trim (CMT) and full price for Russian and Kazakh private agents. The operational capacity is high, due to horizontal integration and high flexibility by small-sized entities and nearby sourcing. However, an analysis of national statistical data highlights the low level of resilience of the Kyrgyz textile sector, due to extreme dependency on sourcing and outlets. This knowledge is of importance to the SME managers in developing appropriate critical success factors (CSFs) amidst various plausible economic and trade scenarios looming for the Kyrgyz transitional economy. SME managers can measure the enterprises' resilience in terms of the capacity to adapt to the changing environment and to redesign their supply chains by enlarging their business network.

For the policy makers this is also of increasing importance to set up a list of normative guidelines at the industry level to safeguard the industry competitiveness, business continuity and resilience in a changing environment. International integration processes have a great influence on production and can redesign the existing supply chain completely. The detailed understanding of the various scenarios and their pros and cons would help the Government and the policy makers modify the international trade regulations to re-estimate the competitive advantage and resilience of the Kyrgyz textile sector.

\subsection{Limitations and future research directions}

The limitations of the research are in terms of methodology. Lack of adequate previous academic research on Kyrgyz industries provides less detail on the influence of the various economic processes, like 'shock therapy', rapid privatisation and liberalisation, juxtaposed with effects of regionalisation in a transitional economy, except that by Sachs (1994b, 1994a) and few others. The research is also limited in terms of using interpretive data analysis tools (SWOT and event-tree), rather than using established scenario planning software. However, the future scope of the research is highly significant, considering the increasing importance of CIS and Customs Union in the international trade arena. Hence future research directions are manifold. Further research can be in terms of investigating deeply the effects of a plausible Customs Union accession on each operational attribute of the Kyrgyz textile sector, especially on textile production with low diversification and specific supply chain properties, possible relational networking, cooperation in triangle manufacturing or regional division of labour, etc. This can be expanded to works on regional clusters in a context of free labour movement principles of the CIS Single Economic Space and inflationary effects of regionalisation. More comparative country cases can be made, e.g., with Poland's 'shock therapy' and its economic impact, or with Kazakhstan's accession to the Customs Union.

Apart from just future research directions, future political decisions are highly motivated in connection to the objectives of the paper. The sector is extremely dependent on political decisions of the Customs Union members, which at any moment can 
bilaterally set up an embargo or non-tariff barriers to textile garments by aggravated certification requirements. Uncertainty of the sector in the middle or long-term also demands reshaping attractiveness for investments in textiles. This makes the challenges for the Kyrgyz textile sector in the conjuncture of international trade regulation, less stable legal base of trade cooperation and other geopolitical and security issues highly relevant in the present environment.

\section{References}

Beardsell, M. and Henderson, V. (1999) 'Spatial evolution of the computer industry in the USA', European Economic Review, Vol. 43, No. 2, pp.431-456.

Birkman, L., Kaloshkina, M., Khan, M., Shavurov, U. and Smallhouse, S. (2012) Textile and Apparel Cluster in Kyrgyzstan, Harvard Kennedy School, Harvard Business School [online] http://www.isc.hbs.edu/pdf/Student_Projects/2012\%20MOC\%20Papers/Kyrgyzstan_Textile\% 20and\%20Apparel\%20Cluster_Final_May\%204\%202012.pdf (accessed 6 February 2014).

Brenner, T. (2004) Local Industrial Clusters: Existence, Emergence and Evolution, Routledge, London and New York.

Burnard, K. and Bhamra, R. (2011) 'Organisational resilience: development of a conceptual framework for organisational responses', International Journal of Production Research, Vol. 49, No. 18, pp.5581-5599.

Canello, J. (2012) 'Regional resilience and evolutionary trends in Marshallian Industrial districts: an empirical investigation using Italian micro-data', 14th ISS Conference, Brisbane, Australia.

Christopher, M. and Peck, H. (2004) 'Building the resilient supply chain', The International Journal of Logistics Management, Vol. 15, No. 2, pp.1-14.

Czap, H.J. and Nur-Tegin, K.D. (2011) 'Big bang vs. gradualism - a productivity analysis', EuroEconomica, Vol. 3, No. 29, pp.38-56.

Fernandez-Jilberto, A.E. and Mommen, A. (1998) Regionalization and Globalization in the Modern World Economy: Perspectives on the Third World and Transitional Economies, Routledge, London.

Fingleton, B., Garretsen, H. and Martin, R. (2012) 'Recessionary shocks and regional employment: Evidence on the resilience of UK regions', Journal of Regional Science, Vol. 52, No. 1, pp.109-133.

Frederick, S. and Gereffi, G. (2009) Review and Analysis of Protectionist Actions in the Textile and Apparel Industries, World Bank and the Center for Economic Policy Research (CEPR), World Bank.

Freeman, S.F. (2004) 'Beyond traditional systems thinking: resilience as a strategy for security and sustainability', 3rd International Conference on Systems Thinking in Management Session on Sustainability, Philadelphia.

Freire, M.R. and Cierco, T. (2007) 'Globalization, regionalization, and europeanization: impact and effects on Polish policy-making', in Fábián, K. (Ed.): Globalization: Perspectives from Central and Eastern Europe (Contemporary Studies in Economic and Financial Analysis) Vol. 89, pp.173-195, Emerald Group Publishing Limited.

Gereffi, G. (1999) 'International trade and industrial upgrading in the apparel commodity chain', Journal of International Economics, Vol. 48, No. 1, pp.37-70.

Gereffi, G. and Fernandez-Stark, K. (2011) Global Value Chain Analysis: A Primer, Center on Globalization, Governance \& Competitiveness (CGGC), Duke University, Durham, North Carolina, USA.

Gereffi, G. and Frederick, S. (2010) The Global Apparel Value Chain, Trade and the Crisis: Challenges and Opportunities for Developing Countries, The World Bank - Development Research Group. 
Gereffi, G. and Memedovic, O. (2003) The Global Apparel Value Chain: What Prospects for Upgrading by Developing Countries, Vienna.

Ghobadian, A. and Gallear, D. (1997) 'TQM and organisation size', International Journal of Operations and Production Management, Vol. 17, No. 2, pp.121-163.

Gittell, J.H., Cameron, K., Lim, S. and Rivas, V. (2006) 'Relationships, layoffs and organizational resilience: airline responses to the crisis of September 11th', The Journal of Applied Behavioral Science, Vol. 42, No. 3, pp.300-329.

Guba, E. and Lincoln, Y.S. (1989) Fourth Generation Evaluation, Sage Publications, Newbury Park.

Gunasekaran, A., Rai, B.K. and Griffin, M. (2011) 'Resilience and competitiveness of small and medium size enterprises: an empirical research', International Journal of Production Research, Vol. 49, No. 18, pp.5489-5509.

Herbane, B. (2010) 'The evolution of business continuity management: a historical review of practices and drivers', Business History, Vol. 52, No. 6, pp.978-1002.

Hettne, B. and Söderbaum, F. (2005) 'Civilian power or soft imperialism? The EU as a global actor and the role of interregionalism', European Foreign Affairs Review, Vol. 10, No. 4, pp.535-552.

Holm, J.R. and Østergaard, C.R. (2013) Regional Employment Growth, Shocks and Regional Industrial Resilience: A Quantitative Analysis of the Danish ICT Sector, Regional Studies [online] http://www.tandfonline.com/doi/abs/ 10.1080/00343404.2013.787159\#.U0GHXfmSySo (accessed 6 April 2014).

Humphrey, J. and Schmitz, H. (2002) 'How does insertion in global value chains affect upgrading in industrial clusters?', Regional Studies, Vol. 36, No. 9, pp.1017-1027.

ILO (2012) Skills for Trade and Economic Diversification in the Kyrgyz Garment Sector, International Labour Organization [online] http://www.ilo.org/wcmsp5/groups/ public/---ed_emp/documents/publication/wcms_182791.pdf (accessed 7 April 2014).

Jin, B. (2004) 'Apparel industry in East Asian newly industrialized countries: competitive advantage, challenge and implications', Journal of Fashion Marketing and Management, Vol. 8, No. 2, pp.230-244.

Katzenstein, K. (2000) 'Regionalism and Asia', New Political Economy, Vol. 5, No. 3, pp.353-370.

Kuhnhardt, L. (2002) Implications of Globalization on the Raison d'être of European Integration, Arena Working papers WP 37, pp.1-55.

Lipton, D., Sachs, J., Fischer, S. and Kornai, J. (1990) Creating a Market Economy in Eastern Europe: The Case of Poland, Brookings papers on Economic Activity, No. 1, pp.75-147.

Martin, R. (2012) 'Regional economic resilience, hysteresis and recessionary shocks', Journal of Economic Geography, Vol. 12, No. 1, pp.1-32.

McGlade, J., Murray, R. and Baldwin, J. (2006) 'Industrial resilience and decline: a co-evolutionary approach', in Garnsey, E. and McGlade, J. (Eds.): Complexity and Co-Evolution: Continuity and Change in Socio-Economic Systems, pp.147-176, Edward Elgar, Cheltenham.

McNiff, J. and Whitehead, J. (2002) Action Research - Principles and Practice, Routledge Farmer, London.

Milberg, W. and Winkler, D. (2010) Trade Crisis and Recovery: Restructuring of Global Value Chains, Policy Research Working paper Series 5294, The World Bank.

National Statistics Committee (2013) Industry of Kyrgyz Republic 2007-2012 [online] http://stat.kg/images/stories/docs/tematika/prom/Prom\%202007-2011.pdf (accessed 17 October 2013).

Pal, R., Andersson, R. and Torstensson, H. (2012) 'Organizational resilience through crisis strategic planning: a study of Swedish textile SMEs in financial crises of 2007-11', International Journal of Decision Sciences, Risk and Management, Vol. 4. Nos. 3/4, pp.314-341. 
Pal, R., Torstensson, H. and Mattila, H. (2014) 'Antecedents of organizational resilience in economic crises - an empirical study of Swedish textile and clothing SMEs', International Journal of Production Economics, Part B, Vol. 147, pp.410-428.

Sachs, J. (1994a) Poland's Jump to the Market Economy, MIT Press, Massachusetts.

Sachs, J. (1994b.) Understanding Shock Therapy, Social Market Foundation, London.

Scholte, J. (2000) Globalization: A Critical Introduction, Palgrave, Basingstoke, UK.

Scholte, J. (2002) 'Civil society and democracy in global governance', Global Governance, Vol. 8, No. 3, pp.281-304.

Sheffi, Y. (2007) The Resilient Enterprise: Overcoming Vulnerability for Competitive Advantage, 1st ed., MIT Press, Cambridge, MA.

Sheffi, Y. and Rice, J.B. (2005) 'A supply chain view of the resilient enterprise', Sloan Management Review, Vol. 47, No. 1, pp.41-48.

Simmie, J. and Martin, R. (2009) 'The economic resilience of regions: towards an evolutionary approach', Cambridge Journal of Regions, Economy and Society, Vol. 3, No. 1, pp.27-43.

USAID (2011) Assessment of the Textile Sector in Kyrgyzstan, USAID Local Development Program [online] http://ldp.kg/wp-content/uploads/2012/07/

Textile-Sector-Assessment-2011.pdf (accessed 6 April 2014).

Van Gils, A. (2005) 'Management and governance in Dutch SMEs', European Management Journal, Vol. 23, No. 5, pp.583-589.

Vilpišauskas, R., Ališauskas, R., Kasčiūnas, L., Dambrauskaitė, Ž., Sinica, V., Levchenko, I. and Chirila, V. (2012) Eurasian Union: A Challenge for the European Union and Eastern Partnership Countries, Public Institution Eastern Europe Studies Centre [online] http://www.eesc.lt/uploads/news/id415/Studija\%20apie\%20Eurazija_EN.pdf (accessed 7 April 2014).

Vossen, R.W. (1998) 'Relative strengths and weaknesses of small firms in innovation', International Small Business Journal, Vol. 16, No. 3, pp.88-94.

Yin, R.K. (2009) Case Study Research: Design and Methods, 4th ed., Sage Publications, London.

Åslund, A., Boone, P. and Johnson, S. (1996) How to Stabilize: Lessons from Post-communist Countries, Brookings Paper on Economic Activity, Vol. 1, pp.217-313.

\section{Notes}

1 Internal Document, Kyrgyz Parliament, 2014. 